\title{
An Analysis of Organisational, Market and Socio-cultural Factors Affecting the Supply of Insurance and Other Financial Services by Microfinance Institutions in Developing Economies*
}

\author{
W. Jean Kwon \\ School of Risk Management, St. John's University, 101 Murray Street, New York, NY 10007, U.S.A. \\ E-mail: kwonw@stjohns.edu
}

This article first investigates the microfinance-principally microinsurance-market at the global level and the business structure of over 600 microfinance institutions (MFIs) in 83 countries that were in operation during 1998-2007. It then empirically examines the impact of organisational, market and socio-cultural factors on the supply of insurance, lending and savings services by MFIs in developing countries. Findings from a series of probit analyses indicate that a rise in the financial expense ratio, loan repayments in arrears, years of operation, number of borrowers, woman borrower ratio, life insurance penetration ratio and family size positively affect MFIs' willingness to expand their operations, certainly to microinsurance business. In contrast, they are likely to stay away from the insurance market when their loan asset ratio, bad loan write-off ratio or average loan size in comparison to GNI per capita is on the rise. It seems MFIs focus on lending service in Muslim populous countries. Finally, we find no evidence that presence of insurance affects availability of savings service, and vice versa, in the microfinance market.

The Geneva Papers (2010) 35, 130-160. doi:10.1057/gpp.2009.32

Keywords: microfinance institutions; microinsurance; supply of insurance; developing economy; socio-culture

\section{Introduction}

Despite occasional recessions, the global economy is expected to continue its long-term growth trend. Yet, the World Bank ${ }^{1}$ classifies 103 out of 209 countries as low-income or lower-middle-income economies (as of July 2008) and reports that almost 1 billion people worldwide survived on a daily income of less than $\$ 1.08$ at 1993 purchasing power parity - a benchmark for the measurement of absolute poverty - in 2004. ${ }^{2}$ Applying a new World Bank benchmark of $\$ 1.25$ a day (introduced in 2008), Ravallion et $\mathrm{al}^{3}$ find that 113 million more Chinese people than previously estimated

\footnotetext{
* A Paper Presented at the Research Round Table of The 2009 Amman, Jordan, International Insurance Society Meeting.

The author thanks Hae-Sik Kim (M.S. graduate) for co-authoring a preliminary study and Ismael Rivera-Sierra with the Kathryn \& Shelby Cullom Davis Library of St. John's University for research support.

${ }^{1}$ World Bank (2008).

${ }^{2}$ World Bank (2007).

${ }^{3}$ Ravallion et al. (2008).
} 
were deemed poor in 2005. Other organisations, such as the UNCDF, ${ }^{4}$ estimate that about four billion people, or 80 per cent of the global population, live in poverty, albeit not all in absolute poverty.

The degree of poverty varies from country to country and even within a local economy, but poor people tend to carry some commonalities. They are low-income earners, face malnutrition and other health risks, and tend to reside in rural areas or in inner-city social sectors. They generally work in informal, non-regulated sectors of the economy ${ }^{5}$ and receive little or no benefits from formal insurance and social security schemes., ${ }^{6,7}$ Many of them are stuck in a "vicious circle of poverty and vulnerability". 8 They have limited ability to deal with personal finance risks.

Poor persons, especially those living in developing economies, have little or virtually no access to the conventional financial services market. Of course, poor people can rely on informal financial risk management arrangements - such as chit fund in India, susu in Gambia and Ghana and other rotating savings and credit associations (ROSCAs) - but those arrangements suffer various deficiencies and lack depth and breadth in service scope. ${ }^{9}$ The leaders in the public and private sectors worldwide as well as those with numerous non-governmental organisations agree that helping people at the base of the economic pyramid participate in the process of economic growth is critical for every country to sustain economic growth. They also agree that microfinance can be a key instrument for the government to manage social equity concerns effectively. Besides, poor people as a group represent a huge consumer market and spend US\$5 trillion for goods and services in the global market. ${ }^{10}$

It is critical to make certain that microfinance is available from institutions operating in a structured financial services market. In an ideal market, financial institutions maintain operational integrity and financial stability and their clients enjoy a systematic protection of their financial interests. In an ideal microfinance market, financial services are standardized - not necessarily uniform — and the regulatory authority assists the market players to achieve efficiency and broaden their product scopes and distribution channels. ${ }^{11}$ Hence, establishment of a structured microfinance market is a condicio sine qua non for a successful elevation of the poverty cycle in the economy. ${ }^{12}$ In a typical microfinance market, we observe three major services: lending for

${ }^{4}$ UNCDF (2005).

${ }^{5}$ Hirway and Charmes (2006).

${ }^{6}$ Dror and Jacquier (1999).

${ }^{7}$ Jacquier et al. (2006).

${ }^{8}$ Churchill (2006).

${ }^{9}$ Skipper and Kwon (2007).

${ }^{10}$ Hammond et al. (2007).

${ }^{11}$ The UNEP Finance Initiative (2007) identifies that building an effective distribution channel, along with agent training and client education programmes, is a key for a financial institution to attain a competitive position in developing economies. See Radermacher et al. (2007) for a discussion about key functional operations (e.g., underwriting and claims management) in the microinsurance market.

${ }^{12}$ Several scholars view that microfinance is to mobilize social capital in an ideal situation (e.g., Rankin, 2006) or to employ an ethical finance system in the local economy (e.g., Torre, 2006). Carter (2007) offers asset-based approaches for the use of microfinance. 
wealth generation; savings for wealth storage and growth; and insurance for wealth protection. ${ }^{13}$

Another requisite for successful microfinance operation is that provision of financial services to the poor should be on a sustainable basis ${ }^{14}$ and the policy of sustainability must be able to induce efficiency improvement and better management practices. ${ }^{15} \mathrm{In}$ this article, we examine these "outreach" and "organisational efficiency" issues in the supply of microfinance services, with an emphasis on insurance service, in the global market during 1998-2007.

This article is structured as follows. In the next section, we analyse the regional and countrywide distribution of microfinance institutions (MFIs) using our initial full data set containing 5,508 observations. We discuss microinsurance and the market for it in this section. The subsequent section offers literature review and discusses model development and data for empirical examination of the organizational, market and socio-cultural factors - including religion (particularly Islam) - that may affect the supply of insurance and other finance services in microfinance markets. Almost all of the countries examined are developing economically, and their insurance markets are either slowly developing or underdeveloped. The penultimate section discusses key findings from the empirical examination. The final section offers conclusions and policy implications.

\section{Microfinance market analysis}

As of May 2008, the Microfinance Information Exchange (MIX) lists 1,205 institutions - inclusive of 329 non-banking financial institutions and 503 non-profit organisations - seeking capital contributions to support their microfinance operations. The list includes 638 MFIs that submit audited financial statements for two consecutive years or more.

We present in Appendix A the distribution of MIX-listed MFIs by organisational type and by country for the financial year of $2007 .{ }^{16}$ The last column of the appendix presents a by-country distribution of the MFIs that participated in microinsurance operations during the year.

Figure 1 illustrates the distribution of MFI assets (in U.S. dollars) by organisational type during 1997-2007. It shows that the relative size of assets owned by banks in the global microfinance market shrunk from 81.3 per cent in 1998 to 44.1 per cent in 2007. During the same period, non-banking financial institutions increased their asset share in the market from 6.4 per cent in 1998 to 25.9 per cent in 2007. The asset share of cooperatives/credit unions rose significantly from 0.4 per cent in 1998 to 15.8 per cent in 2007. The asset share of non-profit organisations remained relatively unchanged during the period and was at 12.3 per cent in 2007.

\footnotetext{
${ }^{13}$ Microfinance institutions may also offer other financial intermediation services (e.g., money transfers and credit cards) and non-financial services (e.g., training).

14 Balkenhole and Churchill (2002).

${ }^{15}$ Vinelli (2002).

${ }^{16}$ Using a different source, Fernando (2006) reports 2,572 microfinance programmes in operation in 2001, including 115 programmes in developed economies.
} 


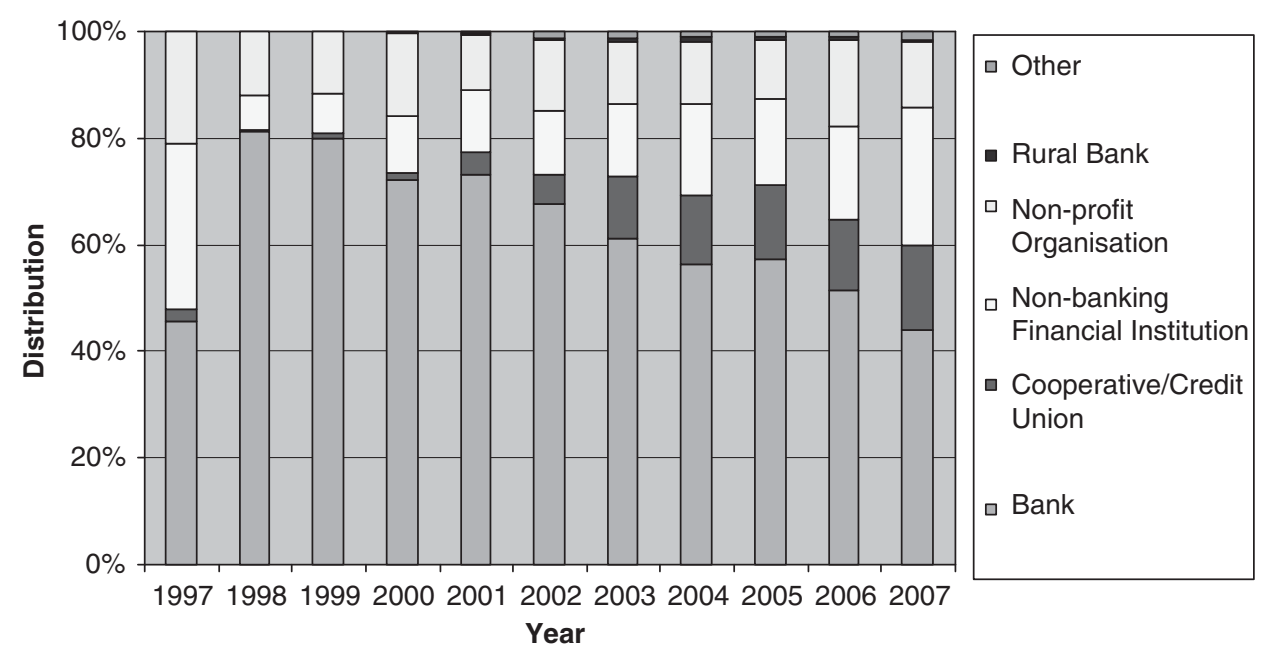

Figure 1. MFI asset distribution by organizational type (1997-2007).

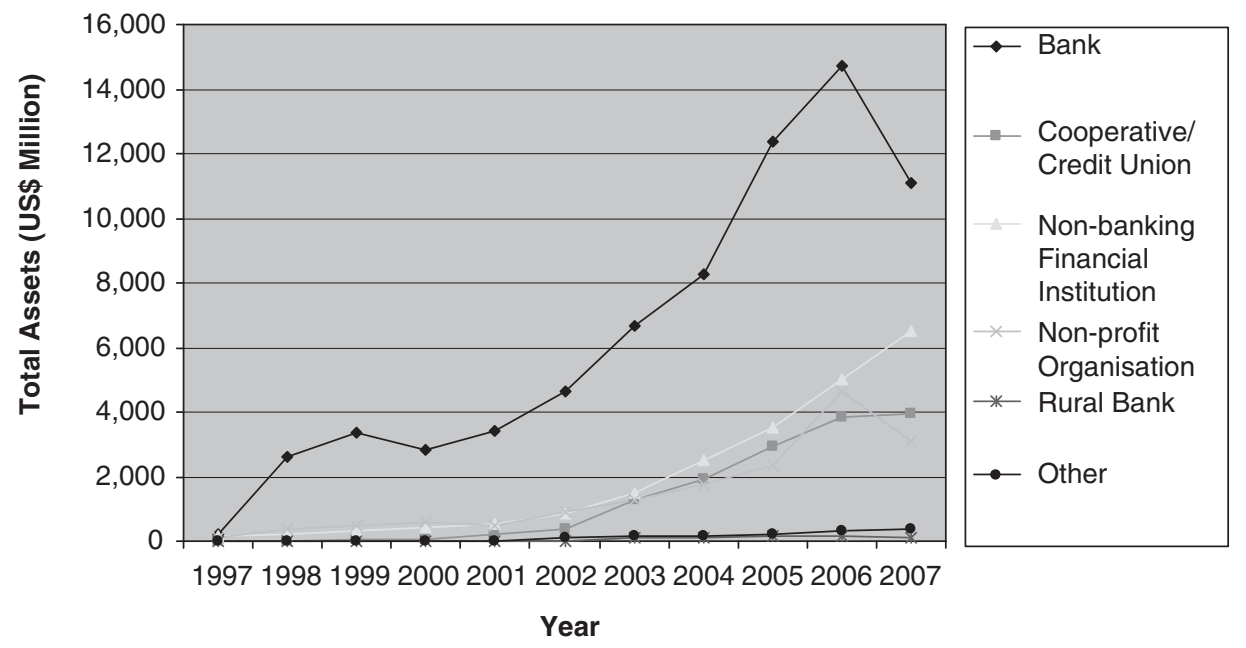

Figure 2. MFI asset growth trend by organizational type (1997-2007).

Figure 2 depicts an asset growth trend in the global microfinance market during the same study period. A leap in the growth rate in 1998 indicates that the microfinance market probably gained its growth momentum in 1998 and thereafter. We observe a sudden decrease in assets owned by banks as well as non-profit organisations in 2007.

Using the MIX data for 2007, we compute the distribution of MFI assets by region. Table 1 shows that MFI assets are concentrated in East Asia and the Pacific. Particularly, the total assets of MFIs in Indonesia alone represent 33.26 per cent of the global market. In contrast, the microfinance market is at its infancy - in terms of asset or loan size - in most countries in the Middle East and North Africa, Eastern Europe 
Table 1 Distribution of assets of microfinance institutions by region in 2007

\begin{tabular}{|c|c|c|c|c|}
\hline \multirow[t]{2}{*}{ Region } & \multicolumn{2}{|c|}{ Asset distribution } & \multicolumn{2}{|c|}{ Loan distribution } \\
\hline & $\begin{array}{c}\text { Amount } \\
\text { (U.S.\$ million) }\end{array}$ & $\begin{array}{l}\text { World market } \\
\text { share }(\%)\end{array}$ & $\begin{array}{c}\text { Amount } \\
\text { (U.S.\$ million) }\end{array}$ & $\begin{array}{c}\text { World market } \\
\text { share }(\%)\end{array}$ \\
\hline East Asia and the Pacific & 9,072 & 59.40 & 5,927 & 55.71 \\
\hline Indonesia & 6,536 & 42.8 & 3,539 & 33.26 \\
\hline Vietnam & 2,265 & 14.83 & 2,195 & 20.63 \\
\hline Other & 271 & 1.77 & 193 & 1.81 \\
\hline Latin America and the Caribbean & 3,488 & 22.84 & 2,836 & 26.66 \\
\hline Peru & 1,237 & 8.10 & 1,018 & 9.57 \\
\hline Mexico & 793 & 5.19 & 674 & 6.34 \\
\hline Columbia & 327 & 2.14 & 301 & 2.83 \\
\hline Paraguay & 282 & 1.85 & 282 & 2.65 \\
\hline Other & 849 & 5.56 & 561 & 5.27 \\
\hline South Asia & 1,857 & 12.16 & 1,164 & 10.94 \\
\hline Bangladesh & 941 & 6.16 & 590 & 5.55 \\
\hline India & 398 & 2.61 & 334 & 3.14 \\
\hline Pakistan & 294 & 1.93 & 127 & 1.19 \\
\hline Other & 224 & 1.47 & 113 & 1.06 \\
\hline Middle East and North Africa & 392 & 2.57 & 329 & 3.09 \\
\hline Morocco & 219 & 1.43 & 205 & 1.93 \\
\hline Jordan & 66 & 0.43 & 55 & 0.52 \\
\hline Egypt & 62 & 0.41 & 36 & 0.34 \\
\hline Other & 45 & 0.29 & 33 & 0.31 \\
\hline Eastern Europe and Central Asia & 251 & 1.64 & 232 & 2.18 \\
\hline Albania & 78 & 0.51 & 74 & 0.70 \\
\hline Kyrgyzstan & 40 & 0.26 & 35 & 0.33 \\
\hline Russia & 32 & 0.21 & 28 & 0.26 \\
\hline Poland & 32 & 0.21 & 32 & 0.30 \\
\hline Other & 101 & 0.66 & 91 & 0.86 \\
\hline Africa & 213 & 1.39 & 150 & 1.41 \\
\hline Kenya & 89 & 0.58 & 62 & 0.58 \\
\hline Mozambique & 42 & 0.28 & 28 & 0.26 \\
\hline Other & 82 & 0.54 & 60 & 0.56 \\
\hline Total & 15,272 & 100.00 & 10,639 & 100.00 \\
\hline
\end{tabular}

Note: This distribution is based on the heat map analysis by the MIX and does not include assets of 281 institutions whose microfinance business represents less than $91 \%$ of their operations in 2007 .

Source: MIX (as of 15 January 2009).

and Central Asia, and Africa. Using the distribution of loans extended by MFIs, we find a similar distribution. In the global microfinance market, total loans represent about 74 per cent of total assets. ${ }^{17}$

${ }^{17}$ An analysis of the 2007 data shows that the following individual financial institutions lead the market in terms of asset or loan portfolio size: BSCS (Colombia), Caja Popular Mexicana (Mexico), Banco Estado (Chile) and Grameen Bank (Bangladesh). 
In terms of the ratio of microfinance customers to total population in 2007, we observe highest percentages in Bangladesh (14.9 per cent) and Mongolia (13.2 per cent). The microfinance penetration percentage is also high in Bosnia and Herzegovina (9.4 per cent), Nicaragua (9.2 per cent), Peru (8.6 per cent), Bolivia (7.7 per cent), Vietnam (6.7 per cent) and Armenia (5.1 per cent). Peachy ${ }^{18}$ reports a similar distribution.

\section{Microinsurance and the microinsurance market}

Microinsurance can be defined simply as "insurance for the poor". This definition identifies the target population but fails to offer any practical guidelines on market operation or regulation. The CGAP Working Group on Microinsurance and the International Association of Insurance Supervisors (IAIS) ${ }^{19}$ jointly offer a more precise definition; that is, "[it] is insurance ... accessed by [the] low-income population, provided by a variety of different entities, but run in accordance with generally accepted insurance practices". ${ }^{20}$ Based on this definition as well as a description of the characteristics of conventional insurance by Skipper and Kwon, ${ }^{9}$ we propose the following traits of microinsurance and the market for it.

Fundamentally, microinsurance should be no different from conventional insurance in that all qualified institutions may underwrite a wide array of risks and distribute their products directly or via intermediaries and all licensed institutions in the market are subject to government regulation and supervision. No authorities are known to set a stringent constraint on product scope. In fact, governments around the world are increasing the scope within which all qualified institutions can operate. In today's markets, however, microinsurance products remain relatively simple in design and carry low coverage limits. This trend reflects in part insurers' intention to commensurate their coverages with the financial protection needs in the target market and in part micro-insureds' affordability of the coverages.

Second, the microinsurance target markets differ from country to country. For example, Dror and Jacquier $^{6}$ argue that microinsurance activities are autonomous, community-based operations and thus microinsurance covers primarily the people who are "excluded" as clients in the conventional financial services market. This contrasts to the view of the IAIS/CGAP that microinsurance services "low-income" people, not necessarily the "excluded". As such, we find the limits of certain life microinsurance policies exceeding US\$10,000 in selected countries. ${ }^{21}$ The consensus is that microinsurance should operate as an insurance programme, and premium payment obligation must be an essential element in all microinsurance

\footnotetext{
${ }^{18}$ Peachy (2007).

19 IAIS (2007).

${ }^{20}$ The Insurance Regulatory and Development Authority of India issued a microinsurance regulation in 2005, which contains a product and coverage-specific guidelines for insurers in the country. See Torkestani and Ahadi (2008) for several other definitions.

${ }^{21}$ Several institutions in Benin, Bolivia, India, Peru, Kyrgyzstan, Ukraine and Uganda report to the MIX that their average loan amounts exceeded $\$ 10,000$ for selected years.
} 
136

contracts. $^{22}$ Any financial assistance that a government or a non-governmental organisation offers victims of a human-made or natural disaster is not a microinsurance programme. This trait implies that the business of microinsurance is likely private sector driven. When the government functions as a supplier of microinsurance, it should run the business according to the same principles to which private institutions in its jurisdiction are subject. Although a government may intend to achieve social equity by adding a cost subsidy element to a particular microinsurance programme, it must make certain that the programme will eventually become self-funded mainly with premium payments and the resulting investment and business income.

Third, microinsurance products range from credit insurance to pure term life insurance, disability insurance, health insurance and basic property insurance. Some cash value life insurance, albeit with a limited savings element, is also observed. ${ }^{23}$ Appendix B presents policy and premium information of selected insurance companies (not necessarily in the microfinance market) we find from the 2006 and 2007 Microinsurance Conference reports.

Finally, offering a bundle of insurance and lending services is increasingly observed in the microfinance market. MFIs expect improvement in operating efficiency from offering a bundle of services and their customers may benefit from low production and distribution cost. ${ }^{24}$ If, however, MFIs add insurance solely as a means to lower their exposures to loan default risk, they are technically forcing their insurance clients to subsidize part of their micro-lending operation costs and the practice can bring about a negative externality in the community. That is, their insurance clients incur an opportunity cost - the value forgone by not consuming another service they prefer (e.g., saving money) - especially when the cost of insurance product bundled with a lending product is higher than the cost of stand-alone insurance product of equivalent quality. ${ }^{25}$ Despite the argument for it - that is, lower loan defaults helps the MFI stay in business and offer loans to more clients - we should evaluate if indeed the benefit from permitting this practice exceeds the cost at the societal level. The issue of (cross) subsidy in the microfinance market is discussed in several studies. ${ }^{26,27}$

The number of MFIs offering insurance service rises. Many, if not all, of them are in the business not as a licensed insurance company but as a corporate agent of one or

${ }^{22}$ Ginneken (2003) argues that premiums for low-income people do not reflect their risks but the services provided. It seems that his definition applies to a social microinsurance programme (e.g., health insurance for low-income people) in the public sector.

${ }^{23}$ Government-led macro-insurance programmes covering natural catastrophe risks as well as privatesector-led meso-insurance programmes dealing with risk securitization are found in selected countries. This article does not discuss these programmes.

${ }^{24}$ See Torre (2006) for presentation of the relationship between financial needs and products in modern microfinance. See Cohen and Young (2007) for a discussion about using microinsurance to protect and accumulate assets.

${ }^{25}$ We observe this practice in the conventional lending market when a lending institution requires borrowers to purchase credit (life) insurance as a loan repayment guarantee. A similar practice is observed in the financial guaranty insurance market.

26 Trezza (2006).

${ }^{27}$ Murdoch (2007). 
more conventional insurance companies. Supply of insurance via referral arrangements with conventional insurers is also observed. From Appendix A we find 222 out of 1,205 MFIs (as of May 2008) participating in microinsurance market operations. We find that 89 out of 235 MFIs, or 38 per cent of the institutions, in South Asia (e.g., India, Bangladesh and Nepal) play a role in the microinsurance market. The percentage is lower in other regions: 22.1 per cent in Latin America and the Caribbean (e.g., Ecuador, Peru, Colombia, Mexico and Bolivia); 15.7 per cent in Africa (e.g., Kenya and Ethiopia); 12.8 per cent in the Middle East and North Africa (e.g., Egypt); 11.5 per cent in East Asia and the Pacific (e.g., the Philippines); and 1.3 per cent in Eastern Europe and Central Asia (e.g., Bosnia and Herzegovina). ${ }^{28}$

\section{Supply of microinsurance and other services: empirical examination}

We find a number of studies about microfinance operations. Many of them discuss microfinance in general or examine micro-lending operations, such as market efficiency, ${ }^{29,30,31}$ operation efficiency, ${ }^{32}$ cost efficiency ${ }^{33,34}$ or the microfinance industry's impact on society. ${ }^{35,36} \mathrm{~A}$ few studies examine micro-savings service as part of microlending service but their study scopes are often limited to a country. ${ }^{37}$

Existing studies about microinsurance often cover a single line of insurance (e.g., health insurance) or a small sample of MFIs. Descriptive country reports are available from several organisations (e.g., reports commissioned by the International Labor Organization and the Consultative Group to Assist the Poor). USAID ${ }^{38}$ offers market research guidelines on the demand for microinsurance. Some studies investigate theoretical aspects in the microinsurance market (e.g., problems of adverse selection) or societal issues (e.g., gender discrimination, social insecurity). Microinsurance product analysis, albeit not empirical, has been conducted by, among others, Brown and Churchill, ${ }^{39}$ Churchill, ${ }^{8}$ Cohen and Young, ${ }^{40}$ Cohen and Sebstad ${ }^{41}$ and McCord and Osinde. ${ }^{42}$ Several studies reports cases of success or failure of microinsurance in selected communities. ${ }^{43,44}$

\footnotetext{
${ }^{28}$ For excerpts of studies about microfinance in developed economies, see Carr and Tong (2002).

29 Armendáriz de Aghion (2005).

${ }^{30}$ Hartarska and Nadolnyak (2008)

${ }^{31}$ Mersland (2009).

32 Oosterhout (2005).

${ }^{33}$ Shankar (2007).

${ }^{34}$ Gutiérrez-nieto et al. (2009).

${ }^{35}$ El Solh (1999).

36 Yasmine (2008).

${ }^{37}$ Lombe and Ssewamala (2007).

${ }^{38}$ USAID (2006).

${ }^{39}$ Brown and Churchill (2005).

${ }^{40}$ Cohen and Young (2007).

${ }^{41}$ Cohen and Sebstad (2005).

${ }^{42}$ McCord and Osinde (2005).

${ }^{43}$ Qurashi and Reinhard (2006, 2007).

${ }^{44}$ See Wright (2006), Milgram (2006) and Ditcher and Harper (2007) for cases of microfinance failure.
} 
A few studies empirically examine microinsurance markets based on a survey of a limited scope. ${ }^{45}$ For example Wipf and Garand ${ }^{46}$ measure microinsurer performance (e.g., net income ratio and growth ratio) using a sample of 10 institutions. Vinelli ${ }^{14}$ tests the relationship between financial self-sufficiency and outreach to the poor in the microfinance market but his study includes data for only 24 MFIs. ${ }^{47}$ A relatively fullscale study is done by $\mathrm{Kim}$ and $\mathrm{Kwon}^{48}$ who use the MIX database of selected MFIs for two years (2006 and 2007).

As discussed earlier, this article empirically examines the efficiency and outreach issues related to supply of microinsurance. We borrow finance, economic and social theories to examine a number of attributes that would induce MFIs to add insurance or savings service to their business portfolios. Based also on the review of existing studies and the analysis of microfinance markets earlier in this article, we identify three sets of factors - organisational, market and socio-cultural - that are likely to affect the supply (presence) of insurance by MFIs in developing economies. We describe each of the variables below in this section and offer a summary of the variables and data sources in Table 2.

The summary table shows the debt-equity ratio has a sample mean of 4.70 and a median of 1.83 . The distribution of the ratio (not shown) indicates that many MFIs are highly leveraged. The loan-to-asset ratio hints that MFI have their assets tied mainly to the lending business. The summaries of the operating expense ratio and the financial expense ratio point that MFIs tend to incur low borrowing costs (on average 4.44 per cent) but high operating expenses (21.22 per cent). MFIs incurred, on average, a low loan write-off ratio (sample mean of 1.83 per cent and median of 0.57 per cent) in the market. ${ }^{49}$

The statistic for the share of loan principals subject to repayments in arrears (Over30) shows that about a quarter of MFIs in the market probably face a serious loan default risk. We find that the average loan amount is US\$848 but the actual loan sizes vary significantly from MFI to MFI and from country to country.

The MFIs in this study has on average 14.18 years of experience, and a little over half of them are regulated. The life insurance markets are developing or underdeveloped in all countries they operate, except South Africa. Life insurance penetration ratios (life insurance premiums divided by GDP) in those developing economies span from almost nil (e.g., Mongolia, Honduras, Cambodia) to 6.02 per cent (El Salvador). ${ }^{50}$ A similar distribution is observed when we use the sum of life and

${ }^{45}$ Also, see: MCII (c.a. 2008) for a review of microinsurance studies; Kim and Kwon (2008) for a summary of studies about the demand for microinsurance; and Dercon et al. (2008) for a sample of insurance companies and their products.

${ }^{46}$ Wipf and Garand (2008).

${ }^{47}$ Vinelli (2002) uses two sets of variables in the study. The outreach set includes the number of borrowers, woman borrower percentage, rural area borrower percentage and average loan. For the financial selfsufficiency set, he employs real interest rate, telephone service availability, Human Development Index, population and infant mortality.

${ }^{48} \mathrm{Kim}$ and Kwon (2008).

49 The write-off distribution seems highly skewed to the right. For example, Kim and Kwon (2008) find cases where the MFI write-off exceeded 60 per cent of the loan portfolio balance.

${ }^{50}$ The ratio for South Africa is greater than 11 per cent for all years. 
Table 2 Summary statistics and data sources

\begin{tabular}{|c|c|c|c|c|c|c|c|}
\hline Categories & Variables & $N$ & Mean & Median & Std. dev. & $L 25(\%)$ & $U 25(\%)$ \\
\hline \multirow{9}{*}{$\begin{array}{l}\text { Organisational } \\
\left(O_{i}\right)\end{array}$} & Debt_equity_R (ratio) $)^{\mathrm{a}}$ & 3,204 & 4.70 & 1.83 & 17.36 & 0.58 & 4.36 \\
\hline & Loan_asset_R $(\%)^{\mathrm{a}}$ & 3,324 & 74.07 & 77.98 & 17.86 & 65.64 & 86.98 \\
\hline & $O p \_e x p \_R(\%)^{\mathrm{a}}$ & 2,803 & 21.22 & 16.93 & 16.47 & 11.12 & 26.30 \\
\hline & $F i \_E x p \_R(\%)^{\mathrm{a}}$ & 2,802 & 4.44 & 3.65 & 4.22 & 1.38 & 6.43 \\
\hline & Write_Off_R $(\%)^{\mathrm{a}}$ & 2,557 & 1.83 & 0.57 & 4.65 & 0.00 & 1.87 \\
\hline & Over30 $(\%)^{\mathrm{a}}$ & 3,018 & 5.00 & 2.70 & 7.67 & 0.79 & 5.99 \\
\hline & $\operatorname{RoA}(\%)^{\mathrm{a}}$ & 2,797 & 37.21 & 13.60 & 287.24 & 6.08 & 25.90 \\
\hline & Assets (U.S.\$ '000) ${ }^{\mathrm{a}}$ & 3,324 & 24,305 & 4,086 & 105,385 & 1,290 & 13,994 \\
\hline & $N G O^{\mathrm{a}}$ & 1,375 out of 3,324 & - & - & - & - & \\
\hline \multirow{5}{*}{$\begin{array}{l}\text { Market } \\
\left(M_{j}\right)\end{array}$} & $Y r s_{-} O p(\text { years })^{\mathrm{a}}$ & 3,324 & 14.18 & 12.00 & 7.76 & 9.00 & 17.00 \\
\hline & Diamond $^{\mathrm{a}}$ & 1,683 out of 3,324 & - & - & - & - & \\
\hline & Regulation $^{\mathrm{a}}$ & 1,674 out of 3,324 & - & - & - & - & \\
\hline & Penet_Life $(\%)^{\mathrm{b}}$ & 2,592 & 0.900 & 0.32 & 2.010 & 0.140 & 0.760 \\
\hline & Interest_R $(\%)^{\mathrm{c}}$ & 2,818 & 18.99 & 16.00 & 11.49 & 11.92 & 22.60 \\
\hline \multirow{7}{*}{$\begin{array}{l}\text { Socio-cultural } \\
\left(S_{k}\right)\end{array}$} & Borrower_No (number) ${ }^{\mathrm{a}}$ & 3,324 & 54,560 & 8,236 & 33,7046 & 2,713 & 24,427 \\
\hline & $L o a n \_G N I \_R(\%)^{\mathrm{a}}$ & 2,716 & 70.98 & 38.82 & 121.91 & 16.16 & 77.16 \\
\hline & Woman_R $(\%)^{\mathrm{a}}$ & 3,036 & 64.40 & 63.20 & 26.85 & 45.00 & 90.65 \\
\hline & Urban_R $(\%)$ & 3,261 & 50.36 & 53.94 & 19.62 & 33.72 & 64.35 \\
\hline & Literacy_R $(\%)^{\mathrm{d}}$ & 3,117 & 77.20 & 85.99 & 19.89 & 66.03 & 92.50 \\
\hline & Family_Size (number) ${ }^{\mathrm{d}}$ & 3,270 & 4.5420 & & 0.8906 & 4.0200 & 5.1000 \\
\hline & Muslim_R $(\%)^{\mathrm{e}}$ & 3,317 & 22.00 & 4.2 & 32.93 & 0.00 & 32.80 \\
\hline \multirow{2}{*}{$\begin{array}{l}\text { Control } \\
\left(C_{l}\right)\end{array}$} & $L A C^{\mathrm{a}}$ & 1,362 out of 3,324 & - & - & - & - & \\
\hline & $S A s i a^{\mathrm{a}}$ & 336 out of 3,324 & - & - & - & - & \\
\hline
\end{tabular}

${ }^{\mathrm{a}}$ Microfinance Information Exchange (MIX).

${ }^{\mathrm{b}}$ Swiss Re, AXCO, MENA Insurance Directory, Insurance Directory of Asia, CIA World Factbook and Euromonitor World Economic Factbook.

${ }^{\mathrm{c}}$ Euromonitor World Economic Factbook.

${ }^{\mathrm{d}}$ CIA World Factbook and Euromonitor World Economic Factbook.

${ }^{\mathrm{e}}$ CIA World Factbook, Euromonitor World Economic Factbook, Islamic Population Index and BBC.

Data sources:

Note: Std. Dev. $=$ Standard deviation; $L 25 \%=$ Lower $25 \% ; U 25 \%=$ Upper $25 \% ;$ Debt_Equity_R $=($ Total liabilities) $\div$ (Total equity) by MFI; Loan_Asset_R=(Gross loan Portfolio) $\div$ (Total assets) by MFI; $O p_{-} E x p_{-} R=$ (Operating expenses) $\div$ (Total assets) by MFI; Fi_Exp_R=(Financial expenses) $\div$ (Total assets) by MFI; Write_Off_R $=$ Bad loans written off to total loan portfolio by MFI; Over30 $=$ Total balance of all outstanding loans with principal repayments overdue 30 days or longer to the total loan portfolio by MFI; RoA = Return on assets; Assets = Total assets in U.S. dollars; Yrs_Op = Years since establishment; Penet_Life $=$ Life insurance premiums to GDP by country; Interest_R $R=$ Average interest rate charged by commercial institutions by country; Borrower_No=Number of borrowers by MFI; Loan_GNI_R=Average loan divided by per capita GNI by MFI; Woman_R = Percentage of female borrowers by MFI; Urban_ $R=$ Percept of population in urbanized areas by country; Literacy_R $=$ Literacy rate (aged $15+)$ by country; Family_Size = Average number of family members by country; Muslim_R= Share of Muslim population in the total population by country. 
140

nonlife insurance penetration ratios (not shown). Most MFIs operate in high-inflation, high-interest markets. For instance, average interest rates in commercial lending markets in the countries range from 5 per cent (Niger in 1999) to 105 per cent (Congo in 2001) per annum. On average, MFIs maintain 8,236 borrowers, and 64.4 per cent of them are women. Literacy rates remain high in most countries that MFI operate. About 22 per cent of the sample populations are Muslim.

For empirical examination, we employ a probit analysis using the following generalized model:

$$
\begin{aligned}
E(\text { Microfinance service })= & f(\text { Organizational factors }, \text { Market factors, } \\
& \text { Socio }- \text { cultural factors }) .
\end{aligned}
$$

Specifically, we test whether the supply of micro-lending, insurance and savings services - alone or together-by MFIs is affected by organisational (firm-specific), market and socio-cultural factors. We discuss them below in this section, beginning with response variables.

\section{Response variables}

We assume that, where permitted, a typical financial institution would first offer lending service and later may extend its business to insurance or savings, if not both. Based on this general assumption, we examine what would cause MFIs to stay put in the lending service only or expand its business into another service line. We run a total of seven tests for the examination.

Given that we only have information about the line or lines of business in which each MFI operates, we categorically code the response variables. For example, the response variable for Test $1\left(Y_{-} A l l\right)$ is coded as follows:

4 if an MFI provides all three services (set as the base);

3 if an MFI provides micro-lending and insurance services only; and

2 if an MFI provides micro-lending and savings services only;

1 if an MFI provides micro-lending service only.

We run Test 2 with $Y_{-}$Both as the response variable where all MFIs in all three service lines are coded 1 and all others 0 . In Test 3, we separate MFIs in the lending business only using Y_Loan. In Test 4, we separate institutions offering both insurance and lending services (coded 1 for coded 1 for $Y$ _LoanInsure) from all others.

Savings service is an integral part of microfinance and several studies support it. For example, Oosterhout ${ }^{32}$ finds evidence that poor people can save up and may view savings as a key survival means to relieve themselves from temporary shortfalls of cash. A study by Rhyne and Christen ${ }^{51}$ suggests that MFIs, especially new entrants, add savings services to attain a competitive edge over their competitors. We examine this aspect using Test 6 where all MFIs offering lending and savings (but not insurance) services are coded 1 in $Y_{-}$LoanSave.

\footnotetext{
${ }^{51}$ Rhyne and Christen (1999).
} 
Finally, we attempt to answer an important question: are insurance and savings services complements or substitutes to each other? Intuitively, the answer depends largely on what products MFIs offer in each line and how they intend to make use of them. Using insurance as an example, we can argue that, on the one hand, microfinance clients voluntarily purchase insurance to hedge the risk of losing current assets and future income. On the other hand, they may prefer saving to insurance, especially when they own no meaningful size of assets or live in a community where people carry a biased view of insurance. As discussed earlier, some MFIs may attempt to control their credit risk by requiring purchase credit or life insurance up to the loan value as a condition to loan approval. We observe some evidence that, in selected cases, credit insurance premiums are based not on the borrower's risk profile but on the loan size (e.g., 0.5 to 2.75 per cent of loan as shown in Appendix B). Roth et al. ${ }^{52}$ also find that consumers may not be satisfied with insurance coverage, especially credit life insurance, provided by MFIs. Whether we can find evidence supporting the aforementioned general assumption or can substantiate the theory that MFIs use insurance for their own benefit is not known a priori. Hence, we add Tests 5 and 7 to check the influence of savings service on insurance consumption and vice versa in the microfinance market. Statistically positive significance of the savings parameter with insurance service as a response (Insurance) in Test 5 will support the general assumption. Statistically negative significance of the insurance parameter with savings service as a response (Savings) in Test 7 will support the latter theory.

\section{Organisational (firm-specific) factors}

We estimate the influence of organisational factors on MFI operations using several variables. Specifically, we use the loan-to-asset ratio (Loan_Asset_R) as an indicator of the importance of lending business in MFI operation. A high loan-to-asset ratio implies that the MFI concentrates its operation in the lending business.

The debt-to-equity ratio (Debt_Equity_R) is employed here to find out whether MFIs would behave differently based on the ratio. We do not know to which direction the influence, if any, would affect MFI operations. For example, based on a general finding that insurance companies are less financially leveraged than banks or investment companies in the conventional market, we expect that MFIs offering insurance service show a lower debt-to-equity ratio than other MFIs in the sample. However, studies indicate that life insurance prevails in the microinsurance market. If found so in our data set, we may find a weak relationship between the ratio and the likelihood of insurance service provision because life business tends to be much more highly leveraged than nonlife (e.g., liability) business.

The operation-expense-to-asset ratio $\left(O P_{-} E x p_{-} R\right)$, where the expenses include salaries and office management expenses, is to measure administrative cost efficiency. MFIs with a low ratio can be viewed relatively efficient in cost management and, ceteris paribus, may be able to expand their business to, say, insurance service. By doing so, they can take advantage of scope economy effects. Alternatively, MFIs with

\footnotetext{
${ }^{52}$ Roth et al. (2007).
} 
a high operation expense ratio probably stay put in the lending market. In contrast, a high financial cost implies a rise in the pressure by creditors for a higher return on their fixed monetary commitments, ${ }^{53}$ thus a higher probability that MFIs facing the pressure may expand business into a new market. We use the financial-expense-toasset ratio $\left(F i_{-} \operatorname{Exp} \_R\right)$ - where the expenses consist of interests, including interests on deposit accounts of clients, and commissions incurred on all liabilities - as a proxy for financial cost.

The rate of return on assets $(R o A)$ instead of return on equity $(R o E)$ is used to measure MFI investment performance. Return on equity tends to remain more stable than $R o A$ from period to period and indicate how effectively MFIs use capital in typical markets. However, we find that the $R o E$ distribution in our data is skewed to extreme far right and its sample mean and standard error (37.22 and 285.81 per cent, respectively) are less reliable than those of $R o A$ (7.35 and 11.55 per cent, respectively).

Two firm-specific factors are used in this article to check the impact of deteriorating loan portfolio quality on MFI operations. First, we use the write-off ratio (Write_off_R), or the total amount of loans written off during the past 12-month period divided by gross loan portfolio. A rise in the ratio indicates worsening loan portfolio quality and MFIs experiencing it would probably resort on insurance, especially credit insurance, to minimise future bad-loan write-offs. Second, we use Over30 - the ratio of the sum of all outstanding principal balances of the loans with principal repayments overdue for 30 days or longer to the entire loan portfolio by MFI - to check the behaviour of MFIs facing a rising loan default risk. Again, we hypothesize that they would probably resort on insurance to manage the risk. This hypothesis is supported by Churchill and Garand ${ }^{54}$ who find that numerous MFIs use insurance to control loan defaults. Roth ${ }^{52}$ also contend that MFIs may use insurance to diversify their revenue (income) sources or to improve profitability by imposing cost subsidy on the insurance line of business.

We assume that large MFIs in terms of total assets would be better prepared to extend their business into savings and insurance than smaller MFIs. We test this assumption using log-transformed assets in U.S. dollars (LnAssets). Similarly, the longer the years of operation, the more likely the MFI has accumulated expertise in microfinance and the higher the probability it offers other services, ceteris paribus. We use the number of years of operation ( $Y r s \_O p$ ) to proxy measure the impact of MFI longevity. Using a dummy-coded $N G O$, we check whether the business scope of non-profit organisations differs from that of other institutions in the sample.

Finally, we examine whether the perceived quality of financial statements would affect MFI's scope of business. For this, we separate MFIs with a Diamond 5 rating (Diamond5) - institutions that disclose complete data including audited financial statements - from those with a Diamond 4 rating - institutions disclosing a minimum

\footnotetext{
${ }^{53}$ Culp (2006).

${ }^{54}$ Churchill and Garand (2006).
} 
of two consecutive years of audited financial statements. The ratings are assigned by the MIX.

\section{Market factors}

Several factors in the local economy can affect MFI operations. For example, Kwon and Chatterjee ${ }^{55}$ argue that the microinsurance market should be subject to stringent government regulation and a sound regulatory environment can stimulate growth of the microinsurance market. We examine the validity of this argument using a regulation dummy (Regulation).

Earlier studies ${ }^{56,57,58}$ suggest presence of a positive relationship between economic growth and insurance market development. In countries with a developed insurance market, citizens are likely aware of insurance benefits and are more willing to consume risk protection products, particularly commodity-type products such as term life insurance. The impact of the insurance industry on the national economy can be estimated using an insurance penetration ratio. Given that life (including health) insurance products prevail in microfinance markets, we employ the life-insurance-premium-to-GDP ratio at the country level (Penet_Life) to proxy measure MFIs' likelihood to engage in insurance service. It is assumed that the higher the penetration ratio, the more likely MFIs in the economy provide insurance service.

All MFIs in this sample offer lending service. In the high interest market, therefore, they face the risk that more borrowers may default their loans and, as a preventive measure, they may impose purchase of credit insurance as a loan approval condition. Hence, we assume a positive relationship between a high interest market environment and supply of insurance service. ${ }^{59}$ Citizens - including MFI clients - in the market are likely to maintain or increase their savings balances. When, however, the high interest rate reflects economic instability in the country as evidenced by high inflation rates in many of the countries in our sample, they would be less inclined to use deposit service to accumulate wealth. As such, the impact of interest rate on savings service provision is not known a priori. Annual average commercial lending rates (Interest_ $R$ ) are used to proxy measure this impact. ${ }^{60}$ Use of interest rates in this study is in line with the assumption by Beck and Webb. ${ }^{61}$

\footnotetext{
${ }^{55}$ Kwon and Chatterjee (2008)

56 Outreville (1990).

${ }^{57}$ Ward and Zurburegg (2000).

${ }^{58}$ Barrese (2008).

${ }^{59}$ We should note that insureds would consume less long-term insurance (e.g., whole life insurance) or long-tail products (e.g., liability insurance) in a high interest market. As discussed, however, products available in the microinsurance markets commonly are for short-term (e.g., up to one year of coverage) and do not have any significant share of savings or investment element.

${ }^{60}$ This study uses interest rates in lieu of inflation rates by country during the study period for the reason that the former reflects more precisely the cost of borrowing money from commercial lenders than the latter.

${ }^{61}$ Beck and Webb (2003).
} 


\section{Socio-cultural factors}

Outreach, or the degree of access to the poor, is viewed as an important goal of all MFIs. ${ }^{62}$ We measure MFIs' success in consumer outreach using several socio-cultural variables. For example, we assume that MFIs with a large client base, in terms of the number of log-transformed borrowers (LnBorrowers) in this article, are successfully achieving the outreach goal and may be willing to offer insurance and savings services further to take advantage of scope economy.

We examine whether MFIs indeed service the poor with the ratio of average loan amount to per capita GNI (Loan_GNI_R). Using a similar proxy, Hume and Mosley ${ }^{63}$ find a positive relationship between loan amount and borrower's income level. Vinelli ${ }^{15}$ also finds that MFIs offering small loans tend to reach a large base of customers. Hence, the smaller the average loan, the more likely the MFI is in the lending market. However, its impact on insurance or savings provision is not known a priori.

It is generally perceived that women in the poor sector commonly neither are financially independent nor work, even if they have a job, in the formal economic sector. Numerous MFIs are said to offer loans to women in the sector so that they can eventually be financially independent, and they often use a group lending approach such as village banking. Holding such a common practice in microfinance markets, we draw two hypotheses. First, group-based lending arrangements can reduce problems of information asymmetry (particularly moral hazard) by encouraging group members to monitor each other's financial matters, thus working as an effective means for MFIs to manage loan default risk. ${ }^{64}$ Second, MFIs using the approach are then less likely to require credit insurance, all other things held constant. In other words, we speculate that compulsory consumption of insurance would be more frequently observed in markets where lending service is extended to individual borrowers than in markets with a village banking system or its variant. ${ }^{65}$ We employ the ratio of female borrowers $($ Woman_R) to measure this impact.

This article attempts to estimate the impact of urbanization, adult literacy and family size. All other things being equal, a rise in urban population (Urban_R) or adult literacy (Literacy_R) would increase consumption of insurance. ${ }^{60,66,67}$ In contrast, in countries with a relatively large family (Family_Size) on average, citizens would have less need for insurance (unless required for loan approval) or savings. Li et al. ${ }^{68}$ also consider family dependency as a potential factor affecting demand for life insurance.

${ }^{62}$ The MIX collects data for per cent of clients below a (national) poverty line, clients with a daily income of less than one dollar, and first time clients. We decide not to use them in this study due to a relatively small number of MFIs reporting the data.

${ }^{63}$ Huma and Mosley (1996).

${ }^{64}$ Cohen et al. (2005).

${ }^{65}$ The village banking system extends loans to groups of clients where members of each group (usually women) are jointly responsible for loan repayments and thus they are likely to monitor each other until the loan is fully repaid. Separately, we should note that if loan borrowers are required to participate in the savings programme, the institution may fail to capture the correct information about clients' real savings potential.

${ }^{66}$ Outreville (1996).

${ }^{67}$ Browne and Kim (1993).

${ }^{68} \mathrm{Li}$ et al. (2007). 
Finally, we are interested in finding out whether religion, particularly Islam, plays a role in the microinsurance market. Several studies ${ }^{69,70}$ find that the takaful insurance market is at its infancy in numerous Muslim populous countries, that many Muslims still perceive insurance (particularly conventional insurance) non-halal, and that Islamic scholars discourage people from purchasing insurance from non-Shariahcompliant financial institutions. Therefore, we assume that microinsurance consumption would be relatively low in Muslim populous countries (Muslim_R). ${ }^{71}$

The final empirical models can be presented as follows:

$$
\begin{gathered}
{\left[\begin{array}{c}
E\left(Y_{\text {All }}\right) \\
E\left(Y_{\text {Loan }}\right) \\
E\left(Y_{\text {Loan Save }}\right) \\
E\left(Y_{\text {Loan Insure }}\right) \\
E\left(Y_{\text {Loan Both }}\right)
\end{array}\right]=\left[\beta_{0}+\beta_{i} O_{i}+\beta_{j} M_{j}+\beta_{k} S_{k}+\beta_{l} C_{l}+\varepsilon\right],} \\
E\left(Y_{\text {Insurance }}\right)=\beta_{0}+\beta_{i} O_{i}+\beta_{j} M_{j}+\beta_{k} S_{k}+\beta_{l} C_{l}+\text { Savings }+\varepsilon, \\
E\left(Y_{\text {Savings }}\right)=\beta_{0}+\beta_{i} O_{i}+\beta_{j} M_{j}+\beta_{k} S_{k}+\beta_{l} C_{l}+\text { Insurance }+\varepsilon,
\end{gathered}
$$

where $E(\boldsymbol{Y})$ are the response variables; $\beta$ s are the parameter estimates; $\boldsymbol{O}_{\boldsymbol{i}}$ is a vector of organisational factors comprising Debt_Equity_R, Loan_Asset_R, Op_Exp_R, Fi_Exp_R, Over30, Ln_Assets, Yrs_Op and $N G O ; M_{j}$ a vector of market factors comprising Regulation, Penet_Life and Interest_R; $\boldsymbol{S}_{k}$ a vector of socio-cultural factors comprising Borrower_N, Loan_GNI_R, Woman_R, Urban_R, Literacy_R, Family_Size and Muslim_R; $\bar{C}_{l}$ a vector of dummies for years $\left(Y R_{-}\right)$, Latin America and the Caribbean $\left(D_{-} L A C\right)$ and South Asia and the Pacific (D_SAsia); and $\varepsilon$ the residual term.

The models include control variables. They are to check financial year effect ( $Y R \_99$ to $\left.Y R \_07\right)$ and possible differences of microfinance service provision in the two regions with a large microinsurance market share: Latin America and the Caribbean $\left(D_{-} L A C\right)$ and South Asia and the Pacific (D_SAsia).

\section{Data}

Multiple sources are used to generate data for this study. All financial institutions in the data offer micro-lending service; that is, the data do not include pure microinsurance companies such as those listed in Appendix B or pure micro-savings institutions. The data cover MFIs in developing economies with an exception of a few MFIs in South Africa.

${ }^{69}$ Kwon (2008).

${ }^{70}$ Karim et al. (2008).

${ }^{71}$ Alternatively, we could employ a dummy variable to separate Shariah principle complying MFIs from others. However, we could not identify any of such MFIs, including microtakaful insurers, in the MIX data. 
Microfinance-specific data are from the MIX database. Among all MFIs in the database, we use only the MFI with a Diamond four or five rating. The study covers a 10-year period beginning from 1998. Data for market factors are from Swiss Re Global Insurance Database, AXCO Insurance Statistics Database, MENA Insurance Directory, Insurance Directory of Asia, CIA World Factbook and Datamonitor's World Economic Factbook. These databases as well as Islamic Population Index and BBC Country Report are used to generate data for socio-cultural factor variables.

The initial data set with 5,508 sample observations is refined as follows. We delete 2,100 of them for not providing key financial data. Also excluded are the observations with zero value for any of the following criteria-gross loans (10 observations), total assets (14) and the number of active borrowers (60). Table 2 is constructed based on analysis of the remaining 3,324 observations. For empirical examination, we delete additional 2,150 observations that have a missing value or more. ${ }^{72}$

The final dataset has 1,125 observations. Of which, 149 observations represents MFIs offering lending service only, 183 lending and savings services, 281 lending and insurance services, and 561 all three microfinance services. We also find that 49.28 per cent of the MFI observations carry a Diamond five rating, 41.37 per cent of them are non-profit organisations, 40.97 per cent of the institutions operate in Latin America and the Caribbean, and 10.11 per cent of them supply services in South Asia. A check of the variables by each group of organisational, market and socio-cultural factors shows no statistically significant correlations.

\section{Key empirical findings}

The findings discussed in this section are based on two statistical models. Table 3 recapitulates key findings from the logistic model-based estimation. Using the probit model, we check the findings from the first model and generate predicted probability distributions (summarised in Figure 3). The conversion criteria in both models are satisfied and the log-likelihood ratios in all logistic tests are statistically significant at the 1 per cent level.

\section{Organisational factors}

The MFI size proxy variable (LnAssets) does not offer us much information except that larger MFIs are more likely in both lending and insurance businesses (Test 4). No statistical evidence is found regarding the impact of the debt-equity ratio (Debt $E q u t y \_R$ ) in all tests, probably because credit and term life insurance products prevail in the microinsurance market. Neither can we find any statistical significance of the investment performance variable $(R o A)$ nor regarding financial statement quality difference between Diamond four and five-rated institutions (Diamond5).

\footnotetext{
${ }^{72} \mathrm{An}$ issue of generalization of the study findings to the global microfinance market thus remains as a study constraint. It should also be noted here that we do not examine hundreds of other MFIs that carry a rating lower than Diamond four.
} 
Table 3 Organisational, market and socio-cultural factors affecting MFI operations

\begin{tabular}{|c|c|c|c|c|c|c|c|}
\hline \multirow[t]{3}{*}{ Variables } & Test 1 & Test 2 & Test 3 & Test 4 & Test 5 & Test 6 & Test 7 \\
\hline & $Y \_$all & Y_Both & $Y_{\text {_Loan }}$ & Y_LoanInsure & Insurance & $Y_{-}$LoanSave & Savings \\
\hline & $\begin{array}{c}\text { Categorical } \\
Y=1,2,3,4\end{array}$ & $\begin{array}{c}Y=1 \text { for } \\
\text { all services }\end{array}$ & $\begin{array}{l}Y=1 \text { for } \\
\text { loan only }\end{array}$ & $\begin{array}{l}Y=1 \text { for loan } \\
\text { and insurance }\end{array}$ & $\begin{array}{l}Y=1 \text { for } \\
\text { insurance }\end{array}$ & $\begin{array}{c}Y=1 \text { for loan } \\
\text { and savings }\end{array}$ & $\begin{array}{c}Y=1 \text { for } \\
\text { savings }\end{array}$ \\
\hline Intercept & $-2.4883^{* * *}$ & $-3.7980 * * *$ & & $-4.3566 * * *$ & $-4.0741 * * *$ & $2.4446 * * *$ & $1.8693 * *$ \\
\hline Intercept 2 & $-1.7500 * *$ & NA & NA & NA & NA & NA & NA \\
\hline Intercept 3 & & NA & NA & NA & NA & NA & NA \\
\hline Savings & NA & NA & NA & NA & & NA & NA \\
\hline Insurance & NA & NA & NA & NA & NA & NA & \\
\hline \multicolumn{8}{|l|}{ Debt_Equity_R } \\
\hline Loan_Asset_R & $-0.7354 * * *$ & & $0.8618 * * *$ & $-1.7689 * * *$ & -1.2595 & & \\
\hline$O p_{-} E x p_{-} R$ & $-1.0521 * * *$ & $-1.9517 * * *$ & $0.9888 * *$ & & & & $-1.1034 * *$ \\
\hline$F i \_E x p \_R$ & $4.2967 * * *$ & $3.2608^{*}$ & $-4.1693 * * *$ & $4.6209 * * *$ & $5.8572 * * *$ & & \\
\hline Write_Off_R & $-2.7781 * * *$ & $-4.9331 *$ & & $-3.2933^{*}$ & $-3.3888^{*}$ & & \\
\hline Over 30 & & & $-1.1473^{*}$ & $2.1761 * * *$ & $1.4634 * *$ & & \\
\hline \multicolumn{8}{|l|}{$\operatorname{RoA}$} \\
\hline LnAssets & & & & $0.1718^{* *}$ & & & \\
\hline$Y r s_{-} O p$ & $0.0128 * * *$ & $0.0318 * * *$ & $-0.0108^{*}$ & $-0.0279 * * *$ & & & $0.0248 * * *$ \\
\hline \multicolumn{8}{|l|}{ Diamond5 } \\
\hline$N G O$ & $-0.7168^{* * *}$ & $-0.7118^{*}$ & $1.0318^{* * *}$ & $0.4079 * * *$ & & $-1.0829 * * *$ & $-1.2957 * * *$ \\
\hline Regulation & & $0.2835^{*}$ & & $-0.3655^{* * *}$ & & $0.2067^{*}$ & $0.3452 * * *$ \\
\hline Penet_Life & $0.0405^{* *}$ & & $0.0551 * *$ & $0.0703 * * *$ & $0.0597 * * *$ & & \\
\hline Interest_R & & $-2.3391^{* * *}$ & & $1.3164 * *$ & & & $-1.4635^{* * *}$ \\
\hline LnBorrowers & $0.1997 * * *$ & $0.1881^{* *}$ & $-0.2002 * * *$ & & $0.1757 * * *$ & & $0.1575 * * *$ \\
\hline Loan_GNI_R & & & & $-0.4226^{* * *}$ & $-0.1503 *$ & $0.1398^{*}$ & $0.2030 * * *$ \\
\hline Woman_R & $0.4513 * * *$ & $1.2711 * * *$ & & & $0.9107 * * *$ & $-0.9099 * * *$ & \\
\hline Urban_ $\bar{R}$ & & $-1.9645^{* * *}$ & & $0.9073^{*}$ & & & $-0.8444 * *$ \\
\hline Literacy_R & & $2.1366^{* * *}$ & $1.3503 * * *$ & & & $-2.2688 * * *$ & $-1.3690 * * *$ \\
\hline Family_Size & $0.1379 * *$ & & $-0.1603^{* *}$ & $0.2368 * * *$ & $0.1962 * * *$ & & \\
\hline Muslim_R & $-1.0476^{* * *}$ & & $1.3036^{* * *}$ & $-0.7421 * *$ & $-0.8398 * * *$ & $-0.9514 * * *$ & $-1.0001 * * *$ \\
\hline$L A C$ & & $-0.8097 * * *$ & & $-0.6543 * * *$ & $-0.2967^{*}$ & $0.2897^{*}$ & $0.3883 * *$ \\
\hline SAsia & & $0.3825^{*}$ & $0.5079 * * *$ & & & $-0.4658^{* *}$ & $-0.5240 * * *$ \\
\hline \multicolumn{8}{|l|}{ YR99 } \\
\hline$Y R 00$ & $-0.3286^{*}$ & & & & & & \\
\hline \multicolumn{8}{|l|}{ YRO1 } \\
\hline$Y R 02$ & & $0.8889^{*}$ & & & & & \\
\hline$Y R 03$ & & & & & & & $-0.3633^{*}$ \\
\hline$Y R 04$ & & $0.8830^{*}$ & & & $0.5222 * *$ & $-0.4051^{*}$ & \\
\hline YR05 & $0.7322 * * *$ & $1.3634 * * *$ & & & $1.0705^{* * *}$ & $-0.9366^{* * *}$ & \\
\hline$Y R 06$ & $0.3415^{*}$ & $0.8676^{*}$ & & $0.7392 * *$ & $0.8727 * * *$ & $-0.6842 * * *$ & \\
\hline$Y R 07$ & $0.4532 * * * *$ & $0.8638^{*}$ & & $0.5233^{*}$ & $0.8509 * * *$ & $-0.5642 *$ & \\
\hline $\begin{array}{l}\text { Log-likelihood } \\
\text { ratio }\end{array}$ & $443.97 * * *$ & $313.45^{* * *}$ & $338.41 * * *$ & $206.81 * * *$ & $323.26 * * *$ & $1244.13^{* * *}$ & $429.80 * * *$ \\
\hline
\end{tabular}

*Statistically significant at the $1 \%$ level; ** Statistically significant at the $5 \%$ level; *** Statistically significant at the $10 \%$ level. 

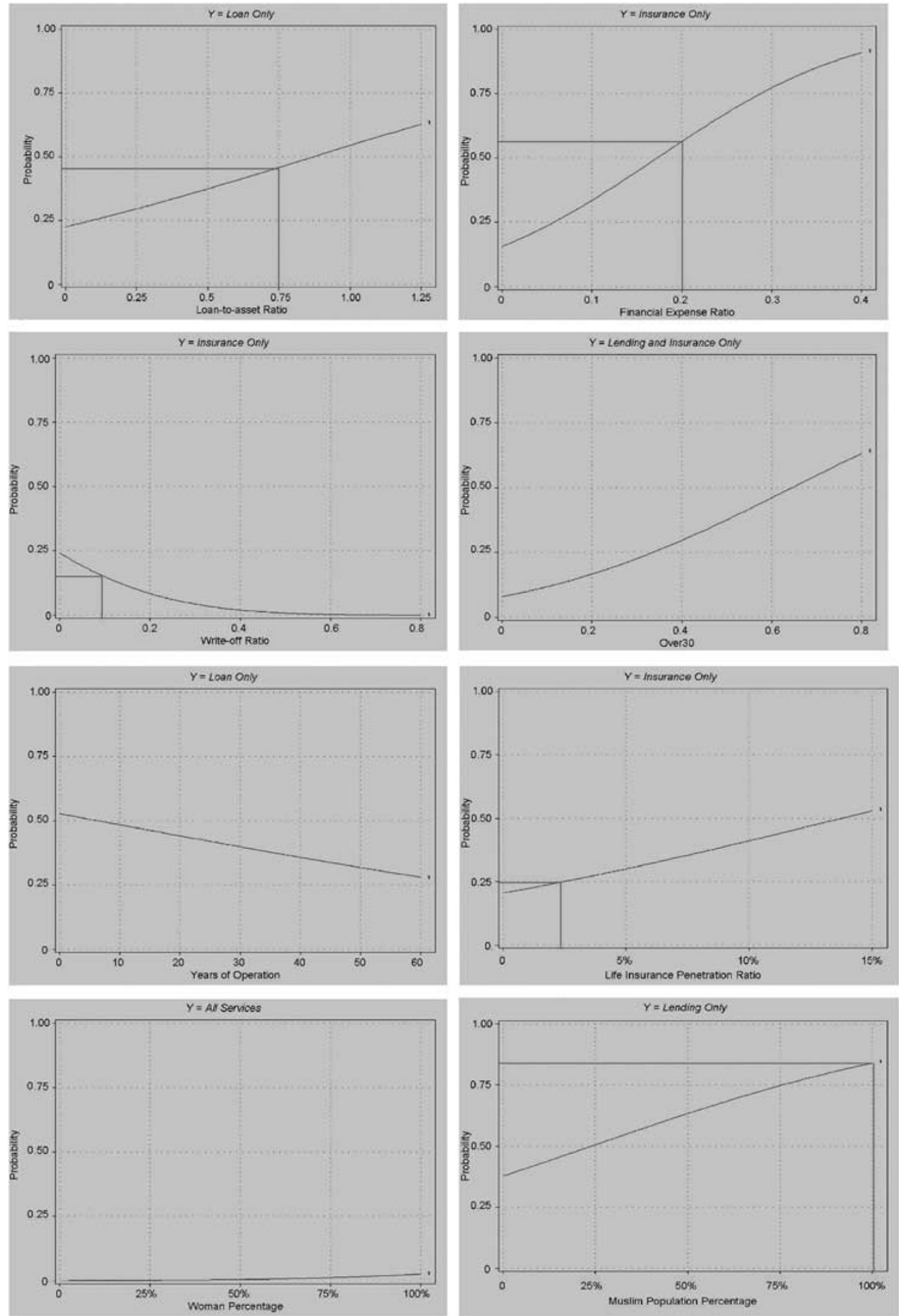

Figure 3. Predicted probability distribution of selected cases. 
As expected, MFIs with a high loan-asset ratio (Loan_Asset_R) are likely in the lending operation only. Other test results support this finding. Specifically, Tests 1 and 2 show that they are less likely to offer or move toward offering all three services. Neither are they more likely to offer lending plus insurance (Test 4). See Figure 3 for a predicted probability distribution of the loan-asset ratio affecting the lending business.

As the operation expense ratio $\left(O p_{-} E x p_{-} R\right)$ rises, MFIs are less likely to expand their business scope (Test 1) and more likely stay in the lending business only (Test 3 ). The probability is low that MFIs with a high ratio operate in all three lines of business (Test 2) or even in the savings market (Test 7). These findings support our hypothesis that MFIs suffering from a high administrative cost burden may lack the capital capacity to expand their business scopes.

A rise in the financial expense ratio $\left(F i_{-} \operatorname{Exp}_{-} R\right)$ stimulates MFIs to broaden their service scope (Test 1) and certainly beyond the initial lending market (Test 3). The findings from other tests suggest that they are probably in multiple lines of business (Test 2), more likely in lending and insurance markets (Tests 4 and 5). For example, Figure 3 presents that the probability that MFIs offer insurance service becomes greater than 0.5 even before their financial expense ratio reaches 20 per cent.

The findings based on the bad-loan write-off ratio $($ Write_Off_R$)$ are inconclusive. We find that MFIs experiencing a rise in the ratio are more likely in all lines of business (Tests 1 and 2). To the contrary, Test 4 indicates that those MFIs would not likely in the insurance business. Test 5 even suggests that they would avoid the insurance market (see also Figure 3).

The impact of the total balance of all outstanding loans at default risk (Over 30$)$ is found to be statistically significant in Tests 3,4 and 5. Together, they suggest that a rise in bad loans cause MFIs to engage in or broaden their service to insurance, further instigating our question whether they would do so to control credit risk against their own borrowers. Also, see Figure 3.

The findings regarding the impact of years in operation (Yrs_Op) indicate that the older MFIs are more likely to offer broad microfinance service (Tests 1 and 2) than the younger MFIs; that is, the former MFIs are less likely in the lending market only (Test 3) but probably offer lending and insurance services (Test 4). Figure 3 also shows a rather gradual negative effect of this factor on the likelihood MFIs staying in the lending market only. Although we do not have statistical evidence whether they would also be in the savings business, the findings from Test 5 suggests that the older MFIs probably offer savings service as well, all other things held constant.

Test results suggest that non-profit organisations $(N G O S)$ are less likely to be in all lines of business than, say, banking and other non-financial institutions (Tests 1 and 2). Neither are they likely put their feet in the savings market. In other words, they are probably in the lending business only (Test 3 ) or may additionally supply insurance services (Test 4).

\section{Market factors}

The test results for the market-economic environment show some impact of government regulation, conventional insurance market development and interest rate. For example, MFIs seem to prefer supply of lending services only (Test 2) or a 
combination of lending and savings services only (Tests 6 and 7) in a regulated market. Microinsurance - alone or in combination with lending services - is less likely available from MFIs when they are subject to government regulation (Tests 4 and 5).

Findings for the life insurance market impact (Penet_Life) draw our attention. We find that growth of the local life insurance market increases the likelihood that MFIs offer not only lending service (Test 3 ) but also insurance service - alone (Test 4) or along with lending service (Test 5). ${ }^{73}$ For example, Figure 3 illustrates that in a country where 2.5 per cent of its GDP is from the life insurance industry, the chance of MFIs offering insurance service is 0.25 .

We find that MFIs in high interest countries are likely to supply both micro-lending and microinsurance service (Test 4) but would probably not be in the savings market (Test 7). As suspected, the latter finding indicates that the real benefit of savings would not be great when MFI clients live in a high inflation country. Test 2 also shows that MFIs in those countries would not offer all services.

\section{Socio-cultural factors}

Potential impact of the socio-cultural environment on MFI operations is found to be comparatively strong in this study. A rise in the number of borrowers (Borrower_No), for example, increases the chance that MFIs move toward and operate in a full-scale service market (Tests 1 and 2), including insurance service (Test 5) and savings services (Test 7). Put differently, they are less likely to be in a monoline (i.e., lending) business (Test 3).

The higher the urban population ratio, the lower the probability that MFIs stay put in the lending market (Test 3 ) or add savings service (Test 7), but the higher the odds that they participate in the microinsurance market. The findings for the population literacy rate (Literacy) are inconclusive. For example, the result from Test 2 indicates a positive impact of the rate on MFIs' likelihood to supply products in all three lines, but the findings from Tests 3, 6 and 7 suggest a contrary position of the MFIs. When an MFI operates in a country where families are relatively large in size (Family_Size), it probably offers more than just lending services (Test 1) and is in insurance service as well (Tests 4 and 5).

A rise in the average loan size as compared to per capita GNI of the country (Loan_GNI_R) seems to make more savings services available from MFIs (Tests 6 and 7). In those markets, insurance service is less likely available (Tests 4 and 5). We do not find any evidence supporting their operations in all service lines or its impact on the lending business.

MFIs with a relatively high percentage of women in the borrower group (Woman_R) are likely to be in two or more lines of business (Tests 1 and 2). Given the statistically positive sign for insurance (Test 5) and the opposite sign for lending and savings (Test 6), we conclude that such MFIs are probably in the lending business or add insurance service. However, the predicted impact of the woman ratio on the supply of insurance, as shown in Figure 3, seems relatively weak.

\footnotetext{
${ }^{73}$ A test using the sum of life and nonlife insurance penetration ratio offers similar findings.
} 
In Muslim populous countries, MFIs tend to be in the lending market only (Test 3). The model predicts that the probability of MFIs offering lending services is around 0.80 in all-Muslim countries (Figure 3). Results from almost all other tests clearly indicate a lower probability that they would add insurance or savings services. This finding supports our assumption that insurance is still not well received in Muslim populous countries.

\section{Control factors}

Those MFIs operating in Latin America and the Caribbean ( $L A C)$ are less likely to offer full-scale microfinance services (Test 2). The odds are that they probably offer savings services (Tests 6 and 7) but not insurance services (Tests 4 and 5). The findings for MFIs in South Asia are inconsistent. The test 2 results shows a higher probability of them offering all services, which contradicts the findings from Tests 6 and 7.

\section{Relationship between microinsurance and micro-savings}

No statistically strong evidence is found about whether presence of savings services would affect the likelihood that MFIs provide insurance services. Neither can we find evidence regarding the impact of insurance service availability on the supply of savings services. A run of the tests using 2006 and 2007 data only (not shown in this article) does not indicate any statistically strong relationship between insurance and savings services. Hence, our findings do not support the contentions by McCord and Osinde, ${ }^{41}$ Roth et al. ${ }^{52}$ They also contrast to the finding by Kim and Kwon ${ }^{74}$ that these services are substitutes for each other.

\section{Conclusions and policy implications}

In this article, we have investigated the status of microfinance markets and the scope of services available from MFIs around the world. We have also examined organisational, market and socio-cultural factors affecting the supply of microinsurance and other financial services using a cross-sectional data for years 1998-2007. Based on the descriptive and empirical examination, we offer the following conclusions.

MFI assets are concentrated in two regions-Latin America and the Caribbean and East Asia and the Pacific. However, microinsurance service is more likely available from MFIs operating in South Asia. The asset share of banks continues to decrease while that of non-profit organisations had gradually risen during 1998-2007.

\footnotetext{
${ }^{74}$ Kim and Kwon (2008).
} 


\section{Supply of all services}

A rise in the financial expense ratio may induce MFIs to broaden their service scope. As the number of lending clients increases, MFIs are more likely to add insurance and savings services, if not both.

\section{Supply of lending services only}

As high loan-asset ratio signals a greater possibility that the MFI focuses at lending service. MFIs are likely to offer lending service only when their operation expenses are on the rise. Non-profit organisations also tend to focus on their operations in the lending market only. In Muslim populated countries, MFIs are more likely to be in the lending market only. In fact, MFIs probably decide not enter the insurance or savings market in those countries.

\section{Supply of lending and insurance services only}

When operating in a market with a rising financial expense rate, a high commercial lending rate or a higher life insurance penetration ratio, MFIs may expand their business to insurance services. The chance of adding insurance services is high among MFIs that observe an increasing amount in their loan portfolios being written off or at default risk. A rise in the percentage of woman borrowers may induce MFIs to stay in the lending business or, although low in probability, add insurance business; such a rise lowers the probability that MFIs offer savings service. MFIs operating in societies with large families or more people living in the urban area may add insurance service but not savings service to their business portfolios.

\section{Supply of lending and savings services only}

As they gain more experience in terms of the number of years in operation, MFIs tend to offer lending and savings services. Government regulation of MFIs affects positively on savings service supply, but negatively on insurance service supply. In the economies where the average loan amount, as compared to the GNI of the economy, is on the rise, MFIs may add savings services but not necessarily insurance services.

\section{Insurance and savings service relationship}

The presence of insurance services do not affect availability of savings services in the microfinance market. Neither does presence of savings services affect MFIs' willingness to supply insurance services. We should note that this article examines the supply of services by MFIs only. As such, we cannot generalise these findings to cases where insurance services are available from pure microinsurance companies. A study based on examination of both types of insurance institutions may offer us some additional insight to the understanding about microinsurance operations.

Finally, Kwon and Chatterjee ${ }^{53}$ find from the MIX data of Diamond four and five institutions for years 2006 and 2007 that 354 of the 672 institutions, or 52.7 per cent, of 
MFIs reported that they were subject to formal regulation. ${ }^{75}$ Nevertheless, they did not observe cross-country consistency regarding the types of institutions subject to such regulation, except that banking institutions are commonly regulated. Enhancement of microfinance market regulation-particularly based on internationally recognised guidelines - is thus called for. The regulatory authority must continuously pay close attention to all major developments in the market not only to protect the interests of borrowers, savers and policy-holders, but also to promote sound development of the market. MFIs also need to raise their self-regulation standards. Otherwise, they may hear again that the microfinance market "has forgotten all about their clients and even big promoters ... offer less attention to the financial behavior/ needs of the poor than they used to". 31

\section{References}

Armendáriz de Aghion, B. (2005) The Economics of Microfinance, Cambridge: MIT Press.

Arab Insurance Group and Ins Communications (annual). MENA Insurance Directory, Singapore: Arab Insurance Group and Ins Communications.

AXCO Insurance Database, www.axco.com.

British Broadcasting Corporation (2005) Muslims in Europe', www.news.bbc.co.uk/2/hi/europe/4385768 .stm (23 December).

Balkenhole, B. and Churchill, C. (2002) 'From microfinance to micro health insurance', in D.M. Dror and A.S. Preker (eds) Social Reinsurance: A New Approach to Sustainable Community Health Financing. Washington, DC: International Labour Office and the World Bank.

Barrese, J. (2008) Insurance penetration and economic development, Working paper (unpublished), St. John's University, New York.

Beck, T. and Webb, I. (2003) 'Economic, demographic, and institutional determinants of life insurance consumption across countries', World Bank Economic Review 17(1): 51-88.

Brown, W. and Churchill, C. (2000) 'Insurance Provisions in Low-income Communities: Part II: Initial Lessons from Micro-Insurance Experiments for the Poor', www.ocdc.coop/publications/insurance provisionpart2lessonslearned.pdf.

Browne, M.J. and Kim, K. (1993) 'An international analysis of life insurance demand', Journal of Risk and Insurance 60: 616-634.

Carr, J. and Tong, Z.Y. (2002) Replicating Microfinance in the United States, Washington, DC: Woodrow Wilson Center Press.

Carter, M. (2007) 'Learning from asset-based approaches to poverty', in C. Moser (ed) Reducing Global Poverty, Washington, DC: Brookings Institution.

Churchill, C. (ed.) (2006) Protecting the Poor: A microinsurance compendium, Geneva: International Labor Organization.

Churchill, C. and Garand, D. (2006) 'Strategies for Sustainability', in C. Churchill (ed.) Protecting the Poor: A Microinsurance Compendium, Geneva: International Labor Organization.

CIA World Factbook International Labor Organisation. https: www.cia.gov/library/publications/the-worldfactbook/index.html.

Cohen, M. and Young, P. (2007) 'Using microinsurance and financial education to protect and accumulate assets', in C. Moser (ed) Reducing Global Poverty, Washington, DC: Brookings Institution.

${ }^{75}$ They report that all MFIs in Cambodia, Ethiopia, Kosovo, Kyrgyzstan, Lebanon, Mongolia, Pakistan and Senegal, among others, are regulated. Local government regulation applies to most of MFIs, for example, in Albania, Armenia, Azerbaijan, Bosnia, Egypt, Honduras, Jordan, Kazakhstan, Mozambique, Nepal, Peru, the Philippines and Uganda. No MFIS in, among others, Costa Rica, Tanzania and Zimbabwe are regulated. 
Cohen, M. and Sebstad, J. (2005) 'Reducing Vulnerability: The Demand For Microinsurance', Journal of International Development 17: 397-474.

Cohen, M., McCord, M.J. and Sebstad, J. (2005) 'Reducing vulnerability: Demand for and supply of microinsurance in East Africa', Journal of International Development 17: 319-325.

Culp, C. (2006) Structured Finance and Insurance: The ART of Managing Capital and Risk, Hoboken: Wiley Finance.

Dercon, S., Kirchberge, M., Gunning, J. and Platteau, J.-P. (2008) 'Literature Review on Microinsurance', www.ilo.org/public/english/employment/mifacility/download/lit_review.pdf.

Dichter, T. and Harper, M. (2007) What's Wrong with Microfinance?, Rugby, Warwickshire: Practical Action Publishing.

Dror, D. and Jacquier, C. (1999) 'Micro-insurance: Extending Health Insurance to the Excluded', International Social Security Review 52(1): 71-97.

El Solh, C. (1999) Feasibility and Operationalization of Microcredit Finance Facilities Targeting Poor Women in Urban and Rural Areas in Selected Arab Countries: Theoretical Perspectives and Practical Considerations, New York: ESCWA, United Nations.

Euromonitor (annual) The World Economic Factbook, London: Euromonitor.

Fernando, J. (2006) 'Microcredit and empowerment of women: Blurring the boundary between development and capitalism', in J. Fernando (ed) Microfinance: Perils and Prospects, New York: Routledge.

Ginneken, W.v. (2003) Extending social security: Policies for developing countries, ESS Paper 13, International Labor Office, Social Security Policy and Development Branch, Geneva.

Gutiérrez-Nieto, B., Serrano-Cinca, C. and Mar Molinero, C. (2009) 'Social efficiency in microfinance institutions', Journal of the Operational Research Society 60(January): 104-119.

Hammond, A., Kramer, W., Katz, R., Tran, J. and Walker, C. (2007) The Next 4 Billion: Market Size and Business Strategy at the Base of the Pyramid, Washington, DC: International Finance Corporation and World Resources Institute.

Hartarska, V. and Nadolnyak, D. (2008) 'Does rating help microfinance institutions raise funds: cross country evidence', International Review of Economics and Finance 17(4): 558-571.

Hirway, I. and Charmes, J. (c.a. 2006) Estimating and understanding informal employment through time use studies, CDFA Working Paper 10, Ahmadabad, India: Inc Communications (annual) Insurance Directory of Asia, Singapore: Inc Communications.

Hume, D. and Mosley, P. (1996) 'Finance against Poverty', London: Routledge.

IAIS (International Association of Insurance Supervisors) (2007) Issues in Regulation and Supervision of Microinsurance, Basel: IAIS.

International Labor Organization (ILO) (2001) Social Security: A New Consensus, Geneva: International Labor Organization.

Islamic Population Index, www.islamicpopulation.com/index.html.

Jacquier, C., Ramm, G., Marcadent, P. and Schmitt-Diabate, V. (2006) 'The social protection on microinsurance', in C. Churchill (ed) Protecting the Poor: A Microinsurance Compendium, Geneva: International Labor Organization.

Karim, N., Tarazi, M. and Reille, X. (2008) 'Islamic microfinance: An emerging market niche', CGAP Focus Note 49(August): 1-15.

Kim,, H.S. and Jean Kwon, W. (2008) An evaluation of distribution channels and supplier efficiency in microinsurance, M.S. thesis (also as an unpublished working paper), St. John's University, New York.

Kwon, W.J. (2008) 'Islamic principle and Takaful insurance: Re-evaluation', Journal of Insurance Regulation 26(1): 53-81.

Kwon, W.J. and Chatterjee, A. (2008) 'Microinsurance: Operation and Regulation Issues', 12th Annual Asia-Pacific Risk and Insurance Association Conference, 6-9 July, Sydney, Australia.

Li, D., Moshirian, F., Nguyen, P. and Wee, T. (2007) 'The demand for life insurance in OECD countries', Journal of Risk and Insurance 74(3): 637-652.

Lombe, M. and Ssewamala, F. (2007) 'The role of informal social networks in micro-savings mobilization', Journal of Sociology \& Social Welfare 34(3): 37-51.

McCord, M.J. and Osinde, S. (2005) 'Reducing vulnerability: The supply of health insurance in East Africa', Journal of International Development 17: 337-381. 
MCII Munich Climate Insurance Initiative (c.a. 2008) 'Microinsurance, Weather-related Risk, and Climate Adaption: A rapid literature review for the Microinsurance Innovation Facility', www.climateinsurance.org/upload/pdf/20080811_mcii_lit_rev_on_microinsur_and_adapt.pdf.

Mersland, R. (2009) 'The cost of ownership in microfinance organizations', World Development 37(2): $469-478$.

Milgram, L. (2006) 'Banking on bananas, crediting crafts', in J. Fernando (ed) Microfinance: Perils and Prospects, New York: Routledge.

MIX Database (Microfinance Information Exchange), www.mixmarket.org.

Murdoch, J. (2007) 'Smart subsidies', in B. Balkenhol (ed) Microfinance and Public Policy, New York: Palgrave Macmillan.

Oosterhout, H.v. (2005) Where Does the Money Go?, Netherlands: Urecht University.

Outreville, J.F. (1990) 'The economic significance of insurance markets in developing countries', Journal of Risk and Insurance 57: 487-498.

Outreville, J.F. (1996) 'Life insurance markets in developing countries', Journal of Risk and Insurance 63: 263-278.

Peachy, S. (2007) 'Microfinance institutions and financial access: The double bottom line', in M. Barr, A. Kumar and R. Litan (eds) Building Inclusive Financial Systems: A Framework for Finance Access, Washington, DC: Brookings Institution.

Qurashi, Z. and Reinhard, D. (2006) Report: Microinsurance Conference 2006, Munich: Munich Re Foundation.

Qurashi, Z. and Reinhard, D. (2007) Report: Microinsurance Conference 2007, Munich: Munich Re Foundation.

Radermacher, R., Dror, I. and Noble, G. (2007) 'Challenges and strategies to extend health insurance to the poor', in C. Churchill (ed) Protecting the Poor: A Microinsurance Compendium, Geneva: International Labor Organization.

Rankin, K. (2006) 'Social capital, microfinance, and the politics of development', in J. Fernando (ed) Microfinance: Perils and Prospects, New York: Routledge.

Ravallion, M., Chen, S. and Sangraula, P. (2008) Dollar a Day Revisited, Washington, DC: World Bank.

Rhyne, E. and Christen, R.P. (1999) Microfinance Enters the Marketplace, Washington, DC: USAID Microenterprise Publications.

Roth, J., McCord, M.J. and Liber, M. (2007) 'The Landscape of Microinsurance in the World's 100 Poorest Countries', www.microinsurancecentre.org.

Shankar, S. (2007) 'Transaction costs in group microcredit in India', Management Decisions 45(8): 1331-1342.

Skipper, H. and Kwon, W.J. (2007) Risk Management and Insurance: Perspectives in a Global Economy, Malden, MA: Blackwell Publishing.

Torkestani, M.S. and Ahadi, P. (2008) 'Readiness assessment of Islamic micro-finance institution to implement micro-insurance concept (case of Iran)', International Journal of Islamic and Middle Eastern Finance and Management 1(3): 249-261.

Torre, M. (2006) 'A new conception of microfinance', in M. La Torre and G. Vento (eds) Microfinance, Hampshire: Palgrave.

Trezza, S. (2006) 'Products and services in modern microfinance', in M. La Torre and G.A. Vento (eds) Microfinance, Hampshire: Palgrave.

UNCDF (United Nations Capital Development Fund) (2005) Microfinance and Millennium Development Goals: A Reader's Guide to the Millennium Project Reports and Other UN Documents, New York: United Nations.

UNEP (United Nations Environmental Programme) Finance Initiative (2007) Insuring for Sustainability, Geneva: UNEP.

USAID (United States Agency for International Development) (2006) Guidelines for Market Research on the Demand for Microinsurance, Washington, DC: USAID.

Vinelli, A. (2002) 'Financial sustainability in U.S. microfinance organizations: Lessons from developing countries', in J.H. Carr and Z.Y. Tong (eds) Replicating Microfinance in the United States, Washington, DC: Woodrow Wilson Center Press.

Ward, D. and Zurburegg, R. (2000) 'Does insurance promote economic development? Evidence from OECD countries', Journal of Risk and Insurance 67(4): 489-506. 
Wipf, J. and Garand, D. (2008) Performance Indicators for Microinsurance: A Handbook for Microinsurance Practitioners, Luxembourg: ADA (jointly with BRA and CGAP Working Group on Microinsurance).

World Bank (2007) Global Monitoring Report 2007: Confronting the Challenges of Gender Equality and Fragile States, Washington, DC: World Bank.

World Bank (2008) Global Monitoring Report 2008: MDGs and the Environment, Washington, DC: World Bank.

Wright, K. (2006) 'The darker side to microfinance', in J. Fernando (ed) Microfinance: Perils and Prospects, New York: Routledge.

Yasmine, F.N. (2008) 'Microcredit and the socio-economic wellbeing of women and their families in Cairo', Journal of Socio-Economics 33(2): 644-656. 


\section{Appendix A}

See Table A1.

Table A1 Distribution of microfinance/insurance institutions by country (Based on all MFIs that have submitted their audited or unaudited financial statements for 2007)

\begin{tabular}{|c|c|c|c|c|c|c|c|c|}
\hline \multirow[t]{2}{*}{ Region and country } & \multicolumn{6}{|c|}{ Institutional type } & \multirow[b]{2}{*}{$\begin{array}{c}\text { Total } \\
\text { number }\end{array}$} & \multirow[b]{2}{*}{$\begin{array}{l}\text { Number of } \\
\text { micro-insurers }\end{array}$} \\
\hline & Bank & $\begin{array}{l}\text { Cooperative/ } \\
\text { credit union }\end{array}$ & $\begin{array}{c}\text { Non-banking } \\
\text { financial } \\
\text { institution }\end{array}$ & $\begin{array}{l}\text { Non-profit } \\
\text { organisation }\end{array}$ & $\begin{array}{l}\text { Rural } \\
\text { bank }\end{array}$ & Other & & \\
\hline Latin America and the Caribbean & & & & & & & 308 & 68 \\
\hline Argentina & & & 3 & 4 & & 1 & 8 & \\
\hline Bolivia & 2 & 2 & 5 & 13 & & & 22 & 7 \\
\hline Brazil & 2 & 1 & & 5 & & 2 & 10 & 3 \\
\hline Chile & 2 & 2 & & 1 & & & 5 & \\
\hline Colombia & 1 & & 1 & 13 & & & 15 & 9 \\
\hline Costa Rica & & & 1 & 10 & & & 11 & 2 \\
\hline Dominican Republic & 2 & & & 4 & & & 6 & \\
\hline Ecuador & 2 & 22 & 1 & 16 & & 1 & 42 & 15 \\
\hline El Salvador & 1 & 4 & 2 & 7 & & 2 & 16 & 5 \\
\hline Grenada & & & 1 & & & & 1 & \\
\hline Guatemala & 1 & & & 15 & & & 16 & 1 \\
\hline Haiti & & & 3 & 3 & & 1 & 7 & \\
\hline Honduras & 1 & & 5 & 8 & & 1 & 15 & 1 \\
\hline Jamaica & & & 1 & & & & 1 & \\
\hline Mexico & 1 & 3 & 21 & 14 & & 1 & 40 & 8 \\
\hline Nicaragua & 1 & 6 & 3 & 19 & & & 29 & 4 \\
\hline Panama & & 1 & 1 & 1 & & & 3 & 1 \\
\hline Paraguay & 1 & 1 & 3 & 1 & & & 6 & 1 \\
\hline Peru & 2 & 6 & 27 & 16 & & & 51 & 10 \\
\hline Saint Lucia & & & 1 & & & & 1 & \\
\hline Trinidad and Tobago & & & & & & 1 & 1 & \\
\hline Uruguay & & & & & & & 1 & 1 \\
\hline Venezuela & & & & & & & 1 & \\
\hline East Asia and the Pacific & & & & & & & 130 & 15 \\
\hline Cambodia & 1 & & 13 & & & & 14 & \\
\hline China & & & 1 & 5 & & & 6 & \\
\hline East Timor & & & 1 & 1 & & & 2 & \\
\hline Indonesia & 2 & 2 & 1 & 5 & 18 & 1 & 29 & \\
\hline Papua New Guinea & & & 1 & & & & 1 & \\
\hline Philippines & 2 & 8 & & 27 & 31 & 2 & 70 & 14 \\
\hline Samoa & & & & 1 & & & 1 & \\
\hline Thailand & & & 1 & 1 & & & 2 & \\
\hline Vietnam & 1 & & 1 & 3 & & & 5 & 1 \\
\hline South Asia & & & & & & & 235 & 89 \\
\hline Afghanistan & 1 & 1 & 3 & 7 & & 2 & 14 & 1 \\
\hline Bangladesh & 1 & & & 67 & & & 68 & 31 \\
\hline India & 1 & 12 & 18 & 65 & 1 & 2 & 99 & 35 \\
\hline Nepal & 1 & 4 & & 7 & 8 & & 20 & 16 \\
\hline Pakistan & 1 & & 6 & 12 & & 1 & 20 & 2 \\
\hline Sri Lanka & 1 & & 8 & 6 & & & 15 & 4 \\
\hline
\end{tabular}


Table A1 (continued)

\begin{tabular}{|c|c|c|c|c|c|c|c|c|}
\hline \multirow[t]{2}{*}{ Region and country } & \multicolumn{6}{|c|}{ Institutional type } & \multirow[b]{2}{*}{$\begin{array}{c}\text { Total } \\
\text { number }\end{array}$} & \multirow[b]{2}{*}{$\begin{array}{l}\text { Number of } \\
\text { micro-insurer }\end{array}$} \\
\hline & Bank & $\begin{array}{l}\text { Cooperative/ } \\
\text { credit union }\end{array}$ & $\begin{array}{c}\text { Non-banking } \\
\text { financial } \\
\text { institution }\end{array}$ & $\begin{array}{c}\text { Non-profit } \\
\text { organisation }\end{array}$ & $\begin{array}{l}\text { Rural } \\
\text { bank }\end{array}$ & Other & & \\
\hline
\end{tabular}

\begin{tabular}{|c|c|c|c|c|c|c|c|c|}
\hline Eastern Europe and Central Asia & 224 & 3 & & & & & & \\
\hline Albania & 1 & 1 & 1 & 3 & & & 6 & \\
\hline Armenia & 2 & & 5 & 2 & & & 9 & \\
\hline Azerbaijan & 2 & 2 & 14 & & & & 18 & \\
\hline Bosnia \& Herzegovina & 2 & & 13 & & & & 15 & 1 \\
\hline Bulgaria & 1 & 3 & 2 & & & & 6 & \\
\hline Croatia (Hrvatska) & & 2 & & & & & 2 & \\
\hline Georgia & 1 & & 7 & 5 & & & 13 & 1 \\
\hline Kazakhstan & & & 21 & 2 & & & 23 & \\
\hline Kosovo & 1 & & 3 & 7 & & & 11 & 1 \\
\hline Kyrgyzstan & 3 & 19 & 11 & & & & 33 & \\
\hline Macedonia (Yugoslav) & 1 & 1 & 1 & 1 & & & 4 & \\
\hline Moldova & & & 3 & & & & 3 & \\
\hline Mongolia & 2 & 1 & 2 & & & & 5 & \\
\hline Montenegro & 1 & & 1 & & & & 2 & \\
\hline Poland & & & 2 & 1 & & & 3 & \\
\hline Romania & 1 & & 6 & & & & 7 & \\
\hline Russia & 2 & 14 & 3 & 3 & & & 22 & \\
\hline Serbia \& Montenegro & 2 & & 1 & 1 & & & 4 & \\
\hline Slovakia & & & & 1 & & & 1 & \\
\hline Tajikistan & 4 & & 18 & 1 & & & 23 & \\
\hline Turkey & & & & 1 & & & 1 & \\
\hline Ukraine & 1 & 1 & 1 & & & & 3 & \\
\hline Uzbekistan & & 2 & & 8 & & & 10 & \\
\hline Africa & & & & & & & 267 & 42 \\
\hline Angola & 1 & & & 1 & & & 2 & \\
\hline Benin & & 6 & & 11 & & 1 & 18 & 1 \\
\hline Burundi & & 1 & & 1 & & & 2 & \\
\hline Burkina Faso & & 1 & 1 & 1 & & & 3 & \\
\hline Cameroon & & 7 & 2 & 1 & 1 & 2 & 13 & 2 \\
\hline Chad & & 1 & & 1 & & & 2 & \\
\hline Congo & 1 & 5 & 4 & 5 & & 1 & 16 & \\
\hline Cöte d'Ivoire & & 8 & 1 & & & & 9 & 2 \\
\hline Ethiopia & & & 16 & & & & 16 & 4 \\
\hline Gabon & & & 1 & & & & 1 & 1 \\
\hline The Gambia & & & 1 & & & & 1 & \\
\hline Ghana & & & 3 & 4 & & & 7 & 1 \\
\hline Guinea & & 1 & 4 & & & & 5 & \\
\hline Kenya & 3 & 1 & 6 & 9 & & & 19 & 7 \\
\hline Liberia & & & & 1 & & & 1 & \\
\hline Madagascar & & 8 & 1 & & & 1 & 10 & \\
\hline Malawi & 1 & 1 & 2 & 5 & & & 9 & 3 \\
\hline Mali & & 9 & & 4 & & & 13 & \\
\hline Mozambique & 3 & & 1 & 4 & & & 8 & 1 \\
\hline Namibia & & & & & & 1 & 1 & 1 \\
\hline Niger & & 3 & & & & & 3 & \\
\hline Nigeria & 1 & & 6 & 3 & & 1 & 11 & 2 \\
\hline
\end{tabular}


W. Jean Kwon Analysis of Organisational, Market and Socio-cultural Factors

Table A1 (continued)

\begin{tabular}{|c|c|c|c|c|c|c|c|c|}
\hline \multirow[t]{2}{*}{ Region and country } & \multicolumn{6}{|c|}{ Institutional type } & \multirow[b]{2}{*}{$\begin{array}{c}\text { Total } \\
\text { number }\end{array}$} & \multirow[b]{2}{*}{$\begin{array}{l}\text { Number of } \\
\text { micro-insurers }\end{array}$} \\
\hline & Bank & $\begin{array}{l}\text { Cooperative/ } \\
\text { credit union }\end{array}$ & $\begin{array}{c}\text { Non-banking } \\
\text { financial } \\
\text { institution }\end{array}$ & $\begin{array}{c}\text { Non-profit } \\
\text { organisation }\end{array}$ & $\begin{array}{c}\text { Rural } \\
\text { bank }\end{array}$ & Other & & \\
\hline Rwanda & 1 & 1 & 5 & & & & 7 & \\
\hline Senegal & & 14 & 1 & 1 & & & 16 & 2 \\
\hline Sierra Leone & 1 & & 1 & 3 & & & 5 & \\
\hline South Africa & 2 & & 3 & 9 & & & 14 & 3 \\
\hline Sudan & & & & 1 & & & 1 & \\
\hline Swaziland & & & 1 & 1 & & & 2 & 1 \\
\hline Tanzania & 1 & & 2 & 6 & 1 & & 10 & 2 \\
\hline Togo & & 8 & & 4 & & & 12 & 2 \\
\hline Uganda & 1 & 6 & 9 & 5 & & 1 & 22 & 4 \\
\hline Zambia & & & 4 & 1 & & & 5 & 2 \\
\hline Zimbabwe & & & 1 & 1 & & 1 & 3 & 1 \\
\hline Middle East and North Africa & & & & & & & 39 & 5 \\
\hline Egypt & 1 & & & 9 & & 1 & 11 & 1 \\
\hline Jordan & & & 4 & 1 & & 2 & 7 & 2 \\
\hline Lebanon & & & 1 & 1 & & & 2 & \\
\hline Morocco & & & & 10 & & & 10 & 1 \\
\hline Palestine & & & & 2 & & 2 & 4 & \\
\hline Syria & & & & & & 1 & 1 & \\
\hline Tunisia & & & & 1 & & & 1 & \\
\hline Yemen & & & 1 & 2 & & & 3 & 1 \\
\hline North America & 1 & 0 & & & & & & \\
\hline United States & & & 1 & & & & 1 & \\
\hline Total & & & & & & & 1205 & 222 \\
\hline
\end{tabular}

Source: the MIX (as of May 2008). 


\section{Appendix B}

See Table B1.

Table B1 Selected cases of microinsurance operation

\begin{tabular}{|c|c|c|c|c|}
\hline Institution & $\begin{array}{l}\text { Country of } \\
\text { operation }\end{array}$ & $\begin{array}{l}\text { Number of } \\
\text { insureds }\end{array}$ & Products & $\begin{array}{l}\text { Premium range } \\
\text { (U.S. dollars, } \\
\text { per person) }\end{array}$ \\
\hline AIG Uganda & Uganda & $1,600,000$ & $\begin{array}{l}\text { Group accident, credit } \\
\text { life }\end{array}$ & $0.5 \%$ of loan \\
\hline Microcare & Uganda & 18,000 & Accident and health & $\$ 15.00 \sim 60.00$ \\
\hline Madison Insurance & Zambia & 31,700 & Loan, funeral & $\begin{array}{l}0.9 \sim 2.75 \% \text { of } \\
\text { loan }\end{array}$ \\
\hline VimoSEWA $^{\mathrm{a}}$ & India & 110,000 & $\begin{array}{l}\text { Voluntary life, health } \\
\text { and asset }\end{array}$ & $\$ 2.38 \sim 5.05$ \\
\hline $\mathrm{RAHA}^{\mathrm{a}}$ & India & 90,000 & Health & $\$ 0.50$ \\
\hline Yeshasvini Trust & India & $1,500,000$ & $\begin{array}{l}\text { Surgery and outpatient } \\
\text { care }\end{array}$ & $\begin{array}{l}\$ 2.72 \text { (half for } \\
\text { child) }\end{array}$ \\
\hline TATA-AIG ${ }^{\mathrm{a}}$ & India & 200,000 & Endowment, group term & $\$ 0.10 \sim 6.70$ \\
\hline TUW SKOK & Poland & $1,500,000$ & $\begin{array}{l}\text { Property, savings, } \\
\text { accidental death \& } \\
\text { disability (AD\&D) }\end{array}$ & $\$ 26.00 \sim 58.00$ \\
\hline MUSCCO & Malawi & 56,000 & Loan and savings & $\begin{array}{l}\$ 0.04 \text { (per } \$ 1,000 \\
\text { cover) }\end{array}$ \\
\hline Delta Life & Bangladesh & $1,000,000$ & Endowment & $\$ 0.90 \sim 1.63$ \\
\hline $\begin{array}{l}\text { Great North Burial } \\
\text { Society }\end{array}$ & South Africa & 9,000 & Funeral & $\$ 3.45$ \\
\hline RAMANSI $^{\mathrm{a}}$ & Philippines & 600,000 & $\begin{array}{l}\text { Life, credit, medical } \\
\text { reimbursement, pension }\end{array}$ & $\$ 6.00 \sim 24.00$ \\
\hline Yasiru $^{\mathrm{a}}$ & Sri Lanka & 87,098 & $\begin{array}{l}\text { Life, accident, health \& } \\
\text { hospitalization, } \\
\text { disability }\end{array}$ & $\$ 0.09 \sim 1.40$ \\
\hline $\begin{array}{l}\text { Aga Khan Development } \\
\text { Network }^{\mathrm{a}}\end{array}$ & Pakistan & 130,000 & Credit, savings, health & $\$ 1.00 \sim 5.00$ \\
\hline $\begin{array}{l}\text { South Indian Federation } \\
\text { of Fishermen Societies }{ }^{\mathrm{a}}\end{array}$ & India & 29,000 & $\begin{array}{l}\text { Life, asset, pension, } \\
\text { fishing equipment }\end{array}$ & $\$ 2.55 \sim 15.27$ \\
\hline $\begin{array}{l}\text { International } \\
\text { Organization for } \\
\text { Migration }^{\mathrm{a}}\end{array}$ & Guatemala & 303 & Health & $\begin{array}{l}\$ 36.00 \sim 450.00 \\
\text { (per family) }\end{array}$ \\
\hline
\end{tabular}

${ }^{a}$ Based on the 2007 conference report.

Source: Microinsurance Conference reports (2006, 2007).

About the Author

W. Jean Kwon, PhD, CPCU is Associate Professor with the School of Risk Management, St. John's University, New York, U.S.A. 